\title{
Exploration on the Course Construction and Teaching Reform of Basic Courses in Agricultural and Forestry Colleges Based on "MOOC"
}

\author{
Wang Yuci \\ Department of Basic Education \\ Beijing University of Agriculture \\ Beijing 102206, China
}

\author{
Zhang Yanfang \\ Department of Basic Education \\ Beijing University of Agriculture \\ Beijing 102206, China
}

\begin{abstract}
Under the background of higher education adopting MOOC, in view of the problems existing in the basic course teaching of agricultural and forestry colleges, this paper discusses the opportunities and challenges brought by the "MOOC" to the course construction and teaching reform of basic courses in agricultural and forestry colleges. The basic course teaching of agriculture and forestry universities should formulate relevant policies according to their own characteristics, encourage teachers to carry out MOOC construction, and conduct teacher training. At the same time, it needs to promote the construction of network teaching platform, upgrade the quality courses, and build MOOC that is suitable for agriculture and forestry universities. It should introduce quality MOOC that is suitable for the basic course teaching of agricultural and forestry colleges, and combine MOOC with "Flip Classroom", so as to deepen classroom teaching reform and improve students' ability to learn independently.
\end{abstract}

Keywords-MOOC; agricultural and forestry colleges; basic course; course construction; teaching reform

\section{THE MEANING AND CHARACTERISTICS OF "MOOC"}

\section{A. The Meaning of MOOC}

Massive Open Online Course (MOOC), also known as large-scale open online courses, is a teaching activity which puts the resources required by teaching activities online, such as teaching video, course introduction, syllabus, reference materials, homework, difficulties and focuses guidance, through network platform based on computer technology and Internet application, and learners acquire knowledge and skills through online learning and interactive communication.

The storm of large-scale online course MOOC began in 2011, and 2012 is called "First Year of MOOC". With the successive establishment of three major MOOC platforms United States Udacity (earliest established, computer courses oriented, fine content, only a few courses), Coursera (biggest MOOC platform currently, rich categories, having both good and bad courses) and edX (established by Harvard and MIT together, flexible course forms) and online release of other courses, the development of MOOC has shown the trend of "blowout". In May 2014, "Chinese University MOOC" on "icourses.cn" was officially launched, and China's higher education began to enter the MOOC era.

\section{B. The Characteristics of MOOC}

First, large scale and rich resources. MOOC is provided by famous universities in many countries. Most of teachers who publish MOOC are very authoritative in the field. They have rich teaching experience, and there are various course categories with fine content. There are many students participating in MOOC, thousands of learners from all over the world can learn online and interact with each other.

Second, open, transparent and various forms. MOOC publishes course resources on the network, and learners choose appropriate courses according to their own preferences and needs. Course content is open and transparent, and in various forms. Time and place are not restricted. The learners' identity and number are also not required. So if there is time, everyone can learn freely.

Third, achieve a learner-led learning method. The role of education is reflected in that the teacher's teaching is for the better study of students. MOOC really restores the nature of learning, and reflects the interaction between teachers and students, students and students. It pays attention to students' learning experience, letting them gradually deepen their understanding of knowledge in the process of interaction and communication.

Fourth, put forward higher requirements for learner's autonomy and self-constraint force. Based on internet platform, there is no face-to-face conversation between teachers and students in MOOC. There is more man-machine dialogue, lack of supervision and restraint mechanisms. Students' interest in learning can't be stimulated by teachers, and the persistence of learning is a difficult problem to solve. And on the internet, it is difficult to ensure that it is learners themselves that are studying and whether the homework is copied or not, and the authenticity of academic level can’t be verified. 


\section{MAin PRoblems IN THE Basic Course TEACHING OF AGRICULTURE AND FORESTRY COLLEGES}

The public basic course of agricultural and forestry colleges mainly refers to basic courses such as mathematics, physics and chemistry and public courses such as English, politics, sports and computer for the first and second grade students. They take up about one third of total class hours. Public basic courses play a leading role in students' study of professional courses. They are of basic, leading and crucial role to the realization of talent training goal. According to the requirements of MOOC, the basic course teaching in agricultural and forestry colleges mainly has the following questions:

\section{A. Teaching mode is lagging behind, not conducive to the cultivation of innovative talents}

The current basic course teaching still uses the traditional teaching methods. 4 to 6 classes have class together. The teacher explains the theoretical knowledge on teaching materials on the podium, while students passively accept the knowledge. Some teachers even just repeat what the book says and never change their teaching plan within decades. Teaching content is obsolete; they can't improve teaching content with the latest teaching and research results or scientific research results. The teaching mode is lagging behind, failing to stimulate students' innovative thinking and innovation ability. Students are lack of learning interest, resulting in low attending rate and pass rate of students. More than half of the students who are not able to graduate each year are because they fail the basic course.

\section{B. Teaching tasks are heavy, not conducive to teaching research}

The basic course teachers have the most important teaching task in the school. Compared with the experiment and internship load of professional course teachers, the class teaching load of basic course teachers is much heavier. Their per capita annual workload reaches 660 hours. Teachers devote most of their time to classroom teaching, and become the so-called "teaching craftsman". There is no time for them to carry out teaching research and teaching reform. At the same time, the lack of teaching results also restricts the development of basic course teachers and affects the improvement of teaching quality.

\section{High scientific research requirements restrict teacher development}

The tradition of paying more attention to scientific research over teaching in the school makes the basic course teachers significantly restricted on title review. Scientific research work is the weakness of basic teachers. For the title review, some teachers spend a lot of time and energy on project declaration and papers publishing, and have no time to take into account the teaching work. Due to various factors, compared to professional teachers, basic course teachers have lower academic qualification, scientific research level and treatment. The development of some young teachers is limited. High-level teachers often go to teach professional courses in colleges. The teaching staff is not stable, and teaching quality is difficult to guarantee.

\section{Course construction and teaching reform are lack of long- term management mechanism}

Despite that some teachers have the enthusiasm to build network courses; they are lack of appropriate financial, technical and managerial support. This results in the fact that the established excellent courses, teaching resources and activities are mostly starting from the perspective of teachers and lack of interaction with students. At the same time, they are lack of analysis and statistics of learning objects, optimal construction of course, and the sharing of course resources. This makes network course become the copy of class teaching activity.

\section{THE OPPORTUNITIES AND CHALLENGES TO BASIC COURSES CONSTRUCTION AND TEACHING REFORM IN AgriculturAl AND Forestry COLLEGES BROUGHT BY "MOOC"}

\section{A. The teaching form of MOOC has obvious advantages in the basic course teaching}

Basic course is open to students of various majors in the school. MOOC breaks the space constraints because of its free learning style and time. It can effectively alleviate the problem of insufficient teachers, and can make high-quality teaching resources be more widely used. For example, use the form of MOOC in the English teaching, and students of different majors can all select the course. In this way, it not only save teachers, but also makes full use of the advantages of MOOC.

\section{B. MOOC makes it possible to teach students in accordance of their aptitude in basic course teaching}

Many students attend the class of basic course in agricultural and forestry colleges, usually four or six classes attending the class together. In most cases, the situation is that teacher lectures on the podium and students listen to the lecturing below. There is not much communication between teacher and students. Through MOOC, teachers can learn the learning situation of each student in real time, giving timely feedback or guidance. They can summarize and analyze teaching laws through recording data of students' learning process and behaviors, so as to improve course content and teaching links in time. Therefore, MOOC makes it possible to teach students in accordance of their aptitude in basic course teaching.

\section{MOOC puts forward higher requirements for basic course teachers}

MOOC can't replace the teacher, or reduce the teacher's teaching tasks. MOOC provides teachers with free teaching space, and it puts forward higher demand for teachers to take good advantage of the teaching space. MOOC gives students the right to select courses, and the teaching quality of teacher determines the number of students who choose the course, which finally determines whether the course will be opened or not. Facing such pressure, teachers need to change the 
teaching attitude and methods, improve teaching level, so as to improve the quality of personnel training. Teachers should realize that their "authority" is challenged. MOOC of famous teachers from famous school is more attractive to students. Teachers should gradually change their role, changing from knowledge transmitter to supervisor and guider of study. They should improve students' self-learning ability and abilities to analyze and solve problems, cultivate students' innovative consciousness and innovation ability.

\section{MOOC puts forward higher requirements for basic courses construction ability}

MOOC construction needs a solid teaching team and a large amount of teaching resources. It requires the common attention of all school leaders and basic course teachers. At present, the attitude of "brought" and "wait and see" will result in unclear understanding and positioning of MOOC construction and low effectiveness of course resources sharing. Even if introducing the industry-recognized high level MOOC, there will still be problems like whether the course is suitable for agricultural and forest colleges, whether it can effectively integrate with various majors to serve the professional courses, whether it is suitable for the personnel training program of different majors, or whether there is a series of supporting management and operation mechanism.

\section{RESEARCH OF BASIC COURSE CONSTRUCTION AND TEACHING REFORM IN AGRICULTURAL AND FORESTRY COLLEGES BASED ON "MOOC"}

\section{A. Formulate relevant policies to encourage teachers to carry out MOOC construction}

We need to attach great importance to the construction of MOOC. We should have clear positioning and understanding. We should neither believe in unrealistic borrowlism, nor can we wait and see in a negative attitude. School and college can develop relevant policies about the construction and operation management methods of MOOC as system guarantee. We need to make provisions about the production requirements, process to open a course, operation and evaluation, credit and work load affirmation of MOOC. At the same time, encourage teachers opening MOOC courses and students who select MOOC courses. Establish special funds, provide financial support and guarantee for MOOC construction and course teaching reform. Organize basic teaching skills competition of young and middle-aged teachers, excellent teacher open class, micro-course competition and other teacher competitions. Build platforms for teachers to communicate teaching experience and show teaching skills, so as to improve teachers' teaching level. Organize MOOC course display and communication in which teachers who participate in MOOC construction display their own MOOC. School and college hire relevant experts and technical staff to discuss about MOOC's content design, teacher and student interaction, teaching resources and other issues. Teachers can learn from each other, and jointly improve the level of MOOC construction. For the teaching load of MOOC, we need to develop corresponding calculation method. The outstanding achievements in MOOC course construction and teaching reform should be taken as important assessment basis in title review and post appointment. We need to stimulate teachers' enthusiasm for MOOC construction and teaching reform, and guide teachers to put more energy in teaching.

\section{B. Carry out teacher training, and promote the construction} of network teaching platform to provide technical support for the construction of MOOC

To strengthen the construction of MOOC, the school should invest in the development of network teaching platform to provide technical support for teachers to carry out mixed teaching. Network teaching platform includes course introduction, syllabus, teaching video, teaching calendar, teacher information, course notification, question and answer discussion, course assignment, online experiment, teaching resources and so on. At the same time, the platform can integrate national excellent courses, global open courses, open video courses, MOOC collection, micro courses and related resources of superstar database and school library, and provide a better network course platform for teachers' teaching and students' studying. Focus on the teaching development of teachers, and carry out relevant training of teachers. On one hand, hire relevant experts and technical staff to carry out special training of how to use the platform and how to construct MOOC based on network platform. On the other hand, encourage teachers to go out to observe and learn domestic and overseas excellent MOOC courses, and finish learning a MOOC course themselves to gain insight into the teaching method of MOOC.

\section{Upgrade excellent courses, and construct MOOC suitable for agriculture and forestry colleges}

We need to create conditions to encourage teachers to upgrade the existing excellent courses, and combine with the characteristics of each major to construct MOOC suitable for agriculture and forestry colleges. This will not only promote the course construction and teaching level of the school, but also can improve the school's influence and popularity, broaden the school's development space through the platform of MOOC. For example, Beijing Agricultural College develops, constructs and manages Beijing excellent course organic chemistry in the form of MOOC. It guides teachers to learn, absorb and draw lessons from domestic and foreign advanced technology, study MOOC's design concept and teaching method, and put teaching research into practice, so as to constantly improve course quality, strengthen teaching reform and build MOOC with the characteristics of agricultural and forestry colleges.

\section{Introduce excellent MOOC suitable for the basic course teaching of agriculture and forestry colleges}

Compared to professional courses, the teaching resources of basic course of agricultural and forestry colleges are in a weak situation. In the case of insufficient construction capacity of the school, we can combine the fact of school and majors, and introduce excellent MOOC courses which are suitable for the basic course teaching of agricultural and forestry colleges. First of all, we need to analyze whether the introduced MOOC course is consistent with the professional 
training programs or the objectives of modern agriculture and forestry personnel training. Second, timely adjust the introduced MOOC course according to the student's academic level and learning interest. For the introduced excellent MOOC courses, the school should equip corresponding MOOC tutor based on the requirements of relevant disciplines to supervise and guide students to study independently and finish corresponding study activities. At the end of the semester, the tutor needs to conduct analysis and statistics of academic record of the course and learning situation of students to constantly improve the introduced excellent MOOC course. For example, since 2014, Beijing Agricultural College has introduced the platform of "Erya Network General Education Course", which includes over 30 MOOC course resources from Peking University, Tsinghua University, Beijing Normal University, Nankai University and other domestic famous schools, from Einstein to Hawking's universe, chemistry and human, the beauty of Chinese poetry, career planning of college students, traditional culture and modern management, hundred-year economics, food safety and daily diet, entrepreneurial management, social psychology, etc. Every MOOC course is equipped with a corresponding tutor.

\section{E. Combine MOOC with "flip classroom" to deepen classroom teaching reform}

Combine "online" MOOC with "offline" classroom teaching. Through MOOC, students can learn classroom teaching related theoretical knowledge in advance, grasp important and difficult points of the course, and interact with the teacher with questions. Or play some MOOC videos in class as needed, and students and teacher can study, watch and interact together, so as to enrich and improve the traditional classroom teaching. According to the characteristic that basic course class has a lot of students, we can take the way of lecturing in big class and discussing in small class. Combine "flip classroom" with MOOC, and carry out mixed teaching, so as to increase the interaction between teacher and students and achieve better teaching effect.

\section{F. Improve students' ability of self-learning, and create a good condition for students to study MOOC}

From the perspective of teaching knowledge, the study of MOOC is the same as that of traditional teaching. They both need students to listen patiently. There is no difference in nature. Some students have poor self-learning ability, and there is no supervision on the Internet. This will let students feel tired, and not be able to finish their studies on time. Some students will even cheat when doing homework or having exam. These are all not controllable in MOOC. Therefore, tutors of MOOC need to help students know their learning objectives stimulate students' enthusiasm for learning, guide them to select courses with purpose. They should know and supervise the learning situation of students in time, and give credit points when finishing the study according to related documents. Improve student status management, assessment management and course election management systems of MOOC. Improve the school's network infrastructure, and try best to provide free wireless network for students in laboratory, study room, library, lecture hall and other places, providing good hardware support for students' MOOC study.

\section{REFERENCES}

[1] Qiao Yuxiang, Zhang Guangya, An Lilong.Design and Practice of Curriculum Construction and Teaching Reform in Local Colleges and Universities under the View of "MOOC" [J]. Higher Agricultural Education, 2016, (3): 62-65.

[2] Sun Yuxia, Liu Peimei, Wei Yihan, etc. MOOC Course Construction Practice and Exploration in Medical School [J]. China Higher Medical Education, 2015, (11): 56-57.

[3] Wu Fengbin. Higher Vocational Education and Teaching Reform Exploration under the Background of "MOOC"[J]. Education and Occupation [J] .2015, (3): 44-45.

[4] Chen Lin, Tang Yiqian, Zhou Mingsheng. The Difficulties and Countermeasures of Application-Oriented Universities Curriculum Construction in MOOC Era[J]. Chinese University Teaching, 2015, (4): 51-53.

[5] Liu Xiuling, Huang Lingyu, Zhu Ruixue, et al. Curriculum Construction Combining with MOOC Resources[J]. Journal of Dalian Nationalities University, 2015, (4): 409-412.

[6] Bao Chonggao, Zhang Jian, Zhao Xin, etc. Promote Basic Course Reform and the Development of Basic Course Teachers[J]. Chinese University Education, 2015, (12): 42-45.

[7] Wu Weizhong, Guan Xiaohui, Qu Chaoyang. The College Teaching Reform Triggered by "MOOC" Wave[J]. Journal of Northeast Normal University (Philosophy and Social Sciences),2015, (2):190-194. 